\title{
From the Editor:
}

Slavic Review publishes letters to the editor with educational or research merit. Where the letter concerns a publication in Slavic Review, the author of the publication will be offered an opportunity to respond. Space limitations dictate that comment regarding a book review should be limited to one paragraph; comment on an article should not exceed 750 to 1,000 words. The editor encourages writers to refrain from ad hominem discourse.

D.P.K.

To the Editor:

I would like to respond to the review of my book Slovakia since Independence: The Struggle for Democracy by Stanislav J. Kirschbaum (Slavic Review 59, no. 1). Kirschbaum's view that my book is flawed by the absence of sources in Slovak is misleading. Most of my sources are Slovak, translated into English on the internet. The implied notion that a political scientist like myself cannot write about Slovak politics without fluency in the Slovak language is absurd. My book provides not only a detailed and extensively documented assessment of the obstacles to Slovak democracy in the political, economic, and sociocultural spheres of national life but also an equally detailed explanation of Slovak relations with Russia and the west, as well as with Slovakia's Visegrad neighbors. Kirschbaum's comment that Praeger should never have published my book is bizarre. As Kirschbaum himself acknowledged, Praeger's reputation as a first-class publishing house is based upon its careful review of potential manuscripts for publication. Slavic Review readers interested in central Europe should ignore Kirschbaum and decide for themselves the credibility and value of my study of postindependence Slovak politics.

Minton F. Goldman Northeastern University

Professor Kirschbaum replies:

In response to Minton Goldman's comment about sources, I can only say that it is no secret that the RFE/RL and other western sources on Slovakia that he used in his book are reports from or summaries or translations of Slovak sources. What must be pointed out, on the other hand, is the fact that they are selective, which is what I say in my review; any researcher who uses them must balance their selectiveness (these sources are also characterized by a primarily negative approach to Slovak politics) with other sources and the most appropriate ones are in the Slovak language. This Goldman has not done and, as he admits, cannot do. His study, as a result, suffers from a lack of balance and is, for this reason, seriously flawed. It is also no secret that publishers often find themselves, for various reasons, in the situation of sending manuscripts if not to sympathetic then to noncritical readers for review. It is a pity that Goldman was not given access to good professional advice. Very little, if anything, is gained, especially for the author, by the publication of a flawed book.

STANISLAV J. KirSCHBAUM York University, Ontario

To the Editor:

In his review of The Radical Right in Eastern and Central Europe since 1989, ed. Sabrina P. Ramet (Slavic Review, 59, no. 3), Paul G. Lewis rightly describes David Ost's article on Poland "as well argued." The readers' attention, however, ought to be drawn to some factual mistakes in this article. The National Democrats were in opposition to the Piłsudski

Slavic Review 60, no. 1 (Spring 2001) 
regime from 1926 on, hence they could not have been, as Ost writes, a "coalition partner in the government on which Hitler declared war in 1939" (86). His reference to "scurrilous tracts of emigre Feliks Koneczny denouncing the Solidarity-era democratic oppositionists" (91) is incomprehensible. Koneczny, a prominent professor of history at Wilno University, was a rightist, but he died in Poland in 1949. His writings on civilization were treated seriously enough to warrant an introduction by Arnold Toynbee to the English-language edition. Finally it is a pity that some spelling errors and the haphazard use of Polish diacritical marks were not corrected.

Piotr S. Wandycz. Yale University

Dr. Lewis declined to reply. 